\title{
SIMULATION MODEL OF THE ADAPTIVE MAINTENANCE PROCEDURE OF COMPLEX RADIOELECTRONIC FACILITIES
}

Lienkov S. V. - Dr. Sc., Professor, Principle Researcher of the Research and Development Establishment of the Military Institute of Taras Shevchenko Kyiv National University, Kyiv, Ukraine.

Zhirov H. B. - PhD, Senior Researcher, Associate Professor of the Chair of Radio Engineering and Radio Electronic Systems of Taras Shevchenko Kyiv National University, Kyiv, Ukraine.

Tolok I. V. - PhD, Head of the Military Institute of Taras Shevchenko Kyiv National University, Kyiv, Ukraine.

Lienkov Ye. S. - PhD, Senior Researcher of the Central Scientific Research Institute of the Armed Forces of Ukraine, Kyiv, Ukraine.

Context. The process of maintenance of modern radio-electronic facilities is aimed at supporting the serviceability or performance of the facilities during their technical operation. Specifications for achieving high reliability of operation are often contrary to other required characteristics, such as reducing the size of the product, obtaining high accuracy, reducing the cost of operation, etc. Therefore, the problem of the optimal choice of maintenance parameters to solve various tasks of operation using different criteria is relevant.

Objective. The objective of this research is developing approaches to determine the optimal parameters of the process of adaptive maintenance.

Method. Within the framework of the general simulation statistic model of the process of maintenance and repair of a complex facility (REF), we have developed a simulation model for parameter optimization of one of the maintenance strategies. The general simulation statistic model is intended to simulate the process of the TMR of the FEF in order to predict the reliability and value of the facility operation. Optimization of maintenance parameters improves both indicators of reliability of the facility and economic indicators of operation of the facility as a whole. The parameters are optimized on the basis of the criterion of a minimum specific cost of the REF operation or the criterion of the maximum ratio of technical use. In both cases, limitation means the required value of the mean time between failures of the facility, and as a method of optimization, we use the method of directed search within the scope of the maintenance parameters. An expert can participate in the process of finding an optimal solution, being involved in the analysis of intermediate data and making a decision on the completion of the search process.

Results. The improved method of optimizing the maintenance parameters is a mathematical and algorithmic basis for the general software of the simulation statistic model of the maintenance and repair process. The method is programmed and tested in solving testing tasks. The results of the computational experiment are illustrated in the tabular form.

Conclusions. In our work we have developed the simulation model of the process of adaptive maintenance of a complex radioelectronic facility. The model enables to substantially simplify and automate the process of research and optimization of the adaptive maintenance parameters of a complex radio-electronic facility. By adding the least reliable elements gradually to a plurality of items subject to servicing and modeling the random moments of the failure time, the simulation model calculates the optimal maintenance options with the adaptive time of condition monitoring. The simulation model is based on the algorithmic model and algorithmic optimization methods for adaptive maintenance, developed in our research, and works in the ISMPN software environment. As a method of optimization, we use the method of directed search within the scope of the maintenance parameters, with a DN distribution as a mathematical reliability model for electronic components and DM distribution for mechanical components.

The practical value of the research lies in developing software which optimizes the maintenance parameters and predicts the reliability and value of operation for the given REF. The results obtained are to be used when determining the requirements for the parameters of operation of both new facilities and those of the available stock.

KEYWORDS: optimization of maintenance parameters, adaptive maintenance.

\author{
ABBREVIATIONS \\ ISMPN is a simulation statistic modeling program; \\ $\mathrm{AM}$ is an adaptive maintenance; \\ $\mathrm{DB}$ is a database; \\ $\mathrm{REF}$ is a radio-electronic facilities; \\ OTM is a operation time maintenance; \\ OCM is an on-condition maintenance.
}

\section{NOMENCLATURE}

$\tilde{a}_{i}\left(t_{k}\right)$ is an estimation of the average degradation rate of the $i$-th element;

$C_{0 i}$ is a cost of the $i$-element;

$C_{\text {repli }}$ is a cost of replacing the $i$-th element;
$C_{\mathrm{m} i}$ is a cost of the maintenance operation for the $i$-th element

$c_{\mathrm{e}}$ is a cost of operation;

$c_{\mathrm{e}}^{+}(\gamma)$ is a function of the specific cost of operation with the optimal value of the maintenance level $u_{\mathrm{m} i}^{+}(\gamma)$;

$c_{\mathrm{e}}^{+}\left(\gamma^{+}\right)$is an optimum value of the specific cost of operation in the current step;

$c_{\mathrm{s} f}$ is a specific cost of the facility in the failure mode;

$c_{\mathrm{S} m}$ is a specific cost, if the facility is in the maintenance state;

$e_{i}$ is an $i$-th constructive element; 
$E_{m}$ is a set of elements maintained;

$E_{m}^{*}$ is a desired set of elements maintained;

$E_{m}^{+}$is a conditionally optimal set of elements maintained;

$K_{s s a}$ is a steady state availability factor;

$K_{s s a}^{+}(\gamma)$ is a function of the steady state availability factor with the optimal value of the maintenance level $u_{\mathrm{To} i}^{+}(\gamma)$;

$K_{\text {ssa }}^{+}\left(\gamma^{+}\right)$is an optimum, in the current step, value of the steady state availability factor;

$L\left(t_{k}\right)$ is a smoothed value for current control time $t_{k}$;

$N_{I}$ is a number of simulations implemented;

$\mathrm{P}_{a m}^{+}$is a conditionally optimal parameters of adaptive maintenance;

$\mathrm{P}_{a m}^{*}$ is an optimal parameters of adaptive maintenance;

$\mathrm{P}_{\mathrm{amc}}^{*}$ is an optimal parameters of adaptive maintenance according to the criterion $\min c_{\mathrm{e}}$;

$\mathrm{P}_{\mathrm{am \kappa}}^{*}$ is an optimal parameters of adaptive maintenance according to the criterion $\max K_{\text {ssa }}$;

$S\left(t_{k}\right)$ is a seasonal value of seasonality at the current time;

$S\left(t_{k-s}\right)$ is a seasonal value for the same period of the previous season;

$s$ is a seasonal period;

$T\left(t_{k}\right)$ is a current trend value;

$T_{c p}^{\prime}\left(t_{k}\right)$ is a current forecast value of the mean time between failures of the least reliable element;

$\widetilde{T}_{m}\left(t_{k}\right)$ is a planned time interval of a regular maintenance;

$T_{0}$ is a mean time between failures;

$T_{0}^{r e q}$ is a required mean time between failures;

$T_{e}$ is a time of operation of the facility;

$t_{k}$ is a current time of the $k$-th maintenance;

$\mathbf{U}_{m}$ is a vector of defining parameters levels, which determines the necessity for maintenance of elements;

$\mathbf{U}_{m}^{*}$ is a required vector of defining parameters levels, which determines the necessity for maintenance of elements;

$\mathbf{U}_{m}^{+}$is a conditionally optimal vector of defining parameters levels, which determines the necessity for maintenance of elements;

$\mathbf{U}_{m i}^{+}$is a conditionally optimal vector of defining parameters levels of elements from the $1^{\text {st }}$ to the $i$-th;

(C) Lienkov S. V., Zhirov H. B., Tolok I. V., Lienkov Ye. S., 2020 DOI 10.15588/1607-3274-2020-1-7 $u_{m i}^{*}$ is a optimal value of the defining parameter obtained in the final ( $i$-th) step;

$u_{m i}^{+}$is a conditionally optimal value of the defining parameter obtained in the last $(i-t h)$ step of modeling;

$u_{m i}^{++}$is an intermediate optimal value of the defining parameter for this step;

$u_{m i}^{+}(\gamma)$ is a function which determines the dependence of the optimal maintenance level of the $i$-th element on the ratio $\gamma$;

$v_{i}$ is a ratio of variation of mean operating time to uni failure of the $i$-th element;

$\alpha$ is a sequence smoothing ratio;

$\beta$ is a trend smoothing ratio;

$\chi$ is a ratio of seasonality smoothing;

$\tau_{\text {repi }}$ is a mean time of replacement of the item of the $i$-th element;

$\tau_{m a}$ is an administrative time for maintenance;

$\tau_{m i}$ is a mean maintenance duration of the $i$-th element;

$\tau_{m c}$ is a mean time of maintenance control;

$\tau_{\text {trou }}$ is a mean time of troubleshooting;

$\varepsilon^{r e q}$ is a the necessary accuracy of the results (relative error);

$\gamma^{*}$ is a desired lead ratio;

$\gamma^{+}$is a conditionally optimal lead ratio.

\section{INTRODUCTION}

The task of providing the necessary indicators of reliability of complex REF arises very often, both in the design of new models of equipment (modernization) and in the operation of available ones. Complex radio-electronic facilities are recoverable facilities of long-term application. The cost of such facilities is high, as well as the costs of operation. Diversity and the stochastic nature of the impact of various operational factors on the radioelectronic facilities result in the fact that, with the same operation time or duration of operation, facilities, in terms of reliability, have different actual technical condition. Due to this fact, operation or calendar time does not expressly characterize the technical condition of the facility.

In order to provide the required level of reliability of REFs during their operation, maintenance and repairs are usually performed, the essence of which is to timely restore the operational condition of the facility and the preventive replacement of the items in the pre-failure condition.

On the one hand, a longer period of maintenance enables to increase the production operation of REF, as well as the operation profitability. But this is not the case with the use of an outdated equipment stock which significantly increases the time of maintenance due to the elimination of intensively increasing failures and malfunctions. 
The object of study is the maintenance process of complex radio-electronic facilities.

The subject of study is optimizing the parameters of adaptive maintenance.

The purpose of the work is to develop approaches to determining the optimal parameters of the process of adaptive maintenance.

\section{PROBLEM STATEMENT}

Depending on the criterion used in determination of the timing of maintenance, there are two main strategies for arranging maintenance: OTM and OCM. When performing OTM, control is exercised according to the available potential of the facility, and when the residual life reduces to some predetermined threshold, the facility maintenance is performed. When conducting OCM, the current technical condition of the facility is monitored, with maintenance performed, if the technical condition of the facility deteriorates to some predetermined unacceptable threshold. In turn, two types of strategies can be identified during OCM: OCM with a constant control period and OCM with a variable control period (adaptive OCM).

Each strategy is characterized by its parameters, which can be simulated using simulation statistic modeling. The modeling criteria of determining parameters of adaptive maintenance in our research are as follows: the criterion for minimizing the specific cost of the facility operation, which is determined at a reference period of operation, with the provision of a reference requirement to the reliability level of the facility, and the criterion of maximizing the coefficient of technical operation with the provision of the same requirement to the reliability level of the facility $[1-4]$.

To perform modeling, it is necessary to create simulation models for all maintenance strategies.

The initial data for ISM are the following variables: $E_{m}, T_{0}^{r e q}, \alpha, \beta$ and $\chi$.

Thus, the article solves an urgent scientific problem in relation to the development of simulation models to optimize the adaptive on-condition maintenance parameters and getting subsequent output variables: $E_{m}^{*}, \mathbf{U}_{m}^{*}$, and $\gamma$. Two criteria are used: optimization by criterion $\min c_{\mathrm{e}}$ and by criterion $\max K_{s s a}$. The limitation is the use of DN distribution, as a mathematical model of reliability of electronic components and DM distribution, for mechanical components.

\section{REVIEW OF THE LITERATURE}

Nowadays, many scientists also investigate the problem of optimizing the maintenance process for different types of facilities. Thus, to minimize the cost of servicing systems with the reliability constraint, work [5] suggests the approach which uses the methods of Lagrangian relaxation embedded in dynamic programming. The approach can be applied to determined and probable tasks of dynamic programming, as well as to Markov partially (C) Lienkov S. V., Zhirov H. B., Tolok I. V., Lienkov Ye. S., 2020 DOI 10.15588/1607-3274-2020-1-7 observable decision making process. The computational complexity of the approach is polynomial with regard to the number of Q-components of the system. The author of work [6] addresses the problem of optimizing maintenance in a multi-component system which performs several missions with scheduled finite discontinuity. Due to the limited time, budget, or availability of resources, maintenance can only be performed on a limited set of components. To do this, we propose a new integrated formulation of nonlinear programming for the sample maintenance, which enables to choose the components to be serviced, the maintenance levels to be performed, and maintenance tasks for several maintenance technicians. In work [7], a stochastic optimization model is considered to reduce the long-term total cost of maintenance complex systems. The work relies on the following principle: optimization of cost models for complex multi-component systems is based on analyzing the reliability of different maintenance approaches (regular block and age ones) and on clustering maintenance actions to reduce the total cost of maintenance of a complex system. In work [8], in accordance with the task of optimizing maintenance, the author selected the most important components of the power system with renewable energy sources. Then a set of maintenance strategies is proposed for all critical components. The total cost of each strategy for all critical components is calculated as the amount of costs for: operation, maintenance and environmental protection. The best maintenance strategy for each critical component is selected by identifying the lowest total cost of different maintenance strategies.

The author of work [9] addresses a new method of optimal strategy of maintenance of a complex system taking into account the reference reliability limitation. It is based on the direct analysis method which provides accurate quantitative determination of the reliability of highly reliable maintenance systems. As a discrete maintenance model, the article considers a model where each maintained component can operate in one or more discrete maintenance modes. In work [10] the author considers the optimal schedule of preventive maintenance of one element on the finite segment on the basis of Bayesian models of the failure function. In work [11] a new approach to the modeling of maintenance of machine tools is developed taking into account the architecture of stock systems. The stock architecture is considered, which consists of various types of machine tools of different manufacturers of equipment, working with different users, but supported by one repair shop. The essence of the approach is to jointly optimize the decisions on the levels of repairs, namely: the schedule of repair, relocation, disposal and preventive maintenance, taking into account the structure of user costs and policy in the workshops. In work [12], the author suggests a new approach to cost-effective optimization of maintenance completion strategies for a set of repaired elements. The optimization method consists of two stages. Firstly, a new concept of matrix modeling is introduced to find the scope for solving this optimization problem. Secondly, a genetic algorithm is used to find a 
solution with minimal costs. It is shown that the combination of matrix modeling and genetic algorithm is a powerful method for solving the problem of optimization. In work [13], the MINLP model is suggested which represents a stochastic process of failures and repairs of the system in the form of a Markov continuous-time chain, on the basis of which the choice of backup and frequency of verification and maintenance tasks is optimized for maximum profit. The model explicitly takes into account all possible conditions of the system. It also offers effective decomposition methods and reduction of maintenance scenarios.

Thus, the task of developing simulation models and improving the procedure of optimizing the adaptive oncondition maintenance parameters for two different criteria is relevant.

\section{MATERIALS AND METHODS}

The development of a simulation model for optimizing the parameters of the process of adaptive maintenance should be based on a pre-formalized adaptive maintenance model. In our work we use an improved model as the formalized model of adaptive maintenance, which is described in works [1]. The optimization task was solved for one of two criteria: optimization by criterion $\min c_{e}$ (1) and by criterion $\max K_{s s a}(2)$ :

$$
\begin{gathered}
c_{e}\left(\left\langle E_{m}^{*}, \mathbf{U}_{m}^{*}, \alpha, \beta, \chi, \gamma^{*}\right\rangle\right) \rightarrow \min , \\
T_{0}\left(\left\langle E_{m}^{*}, \mathbf{U}_{m}^{*}, \alpha, \beta, \chi, \gamma^{*}\right\rangle\right) \geq T_{0}^{r e q} \\
K_{s s a}\left(\left\langle E_{m}^{*}, \mathbf{U}_{m}^{*}, \alpha, \beta, \chi, \gamma^{*}\right\rangle\right) \rightarrow \max .
\end{gathered}
$$

Constants of smoothing are not directly related to the choice of maintenance options. For this reason, the parameters $\alpha, \beta, \chi$ are not included in the number of optimized strategy parameters, and we regard them as constants.

When solving a problem (1) the set $E_{m}$ is fixed, with the sequence of partial problems solved. At each step, an auxiliary set $E_{m}^{+}$is formed by adding one element from the set $E_{m}$, with a specific task solved for determining the optimal parameters satisfying the condition:

$$
c_{e}\left(\left\langle E_{m}^{*}, \mathbf{U}_{m}^{*}, \alpha, \beta, \chi, \gamma^{*}\right\rangle\right) \rightarrow \min _{U_{m}, \gamma}
$$

Solution $\mathrm{P}_{a m}^{+}=\left\langle E_{m}^{+}, U_{m}^{+}, \gamma^{+}\right\rangle$satisfying condition (3) is a conditionally optimal solution obtained, if the set of maintained elements consists of $E_{m}^{+}$, and $\mathbf{U}_{m i}^{+}=\left\{u_{m 1}^{*}, u_{m 2}^{*}, \ldots, u_{m i}^{+}\right\}[1,16]$.
When adding new elements to $E_{m}^{+}$, the mean time between failures $T_{0}$ should increase, and when the requirement $T_{0} \geq T_{0}^{r e q}$ is met in a certain step, the process of search for a conditionally optimal solution is completed. This solution, obtained in the final stage, is taken as the general optimal one $\mathrm{P}_{a m}^{*}$.

Figure 1 shows the algorithmic model of the task solution (1)

Statement 1 generates the output data: the set of the maintained elements $E_{m}$; records constants of smoothing.

Statement 2 creates empty sets $E_{\mathrm{m} i}^{+}$and $U_{\mathrm{m} i}^{+}$, and initiates the variable $i$, which is used to calculate the number of steps for a solution search (simultaneously, the variable $i$ is the number of element $e_{i}$ which is added to the set $E_{m i}^{+}$). The set $E_{m i}^{+}$is used as the current set of maintained elements (one element from the set $E_{m}$ will be added at each stage). A set $\mathbf{U}_{m i}^{+}$is used to memorize the obtained optimal values of the maintenance levels $u_{m i}^{+}$of elements included in the set $E_{m i}^{+}$.

Statement 3 forms the number $i$ of the next (current) step of the search process.

Statement 4 chooses $i$-th element $e_{i}$ from the set $E_{m}$ and adds it to the set. The elements $e_{i}$ from the set $E_{m}$ are selected in ascending order of their mean time between failures.

Statement 5 makes function charts $u_{m i}^{+}(\gamma)$ and $c_{e}^{+}(\gamma)$ depending on the value of the lead ratio $\gamma$, which binds the scheduled time interval to the next maintenance $\widetilde{T}_{m}\left(t_{k}\right)$, with the current predicted value of the mean time between failures of the least reliable element $T_{c p}^{\prime}\left(t_{k}\right)$ :

$$
T_{c p}^{\prime}\left(t_{k}\right)=\frac{1}{\widetilde{a}_{i}\left(t_{k}\right)} .
$$

For a two-parameter exponential smoothing model, estimation of the average degradation rate of the $i$-th element is determined by the expression:

$$
\begin{gathered}
\tilde{a}_{i}\left(t_{k+1}\right)=L\left(t_{k}\right)+T\left(t_{k}\right), \\
L\left(t_{k}\right)=\alpha \cdot a_{i}\left(t_{k}\right)+(1-\alpha)\left[S\left(t_{k-1}\right)-T\left(t_{k-1}\right)\right] \\
T\left(t_{k}\right)=\beta\left(S\left(t_{k}\right)-S\left(t_{k-1}\right)\right)+(1-\beta) \cdot T\left(t_{k-1}\right)
\end{gathered}
$$




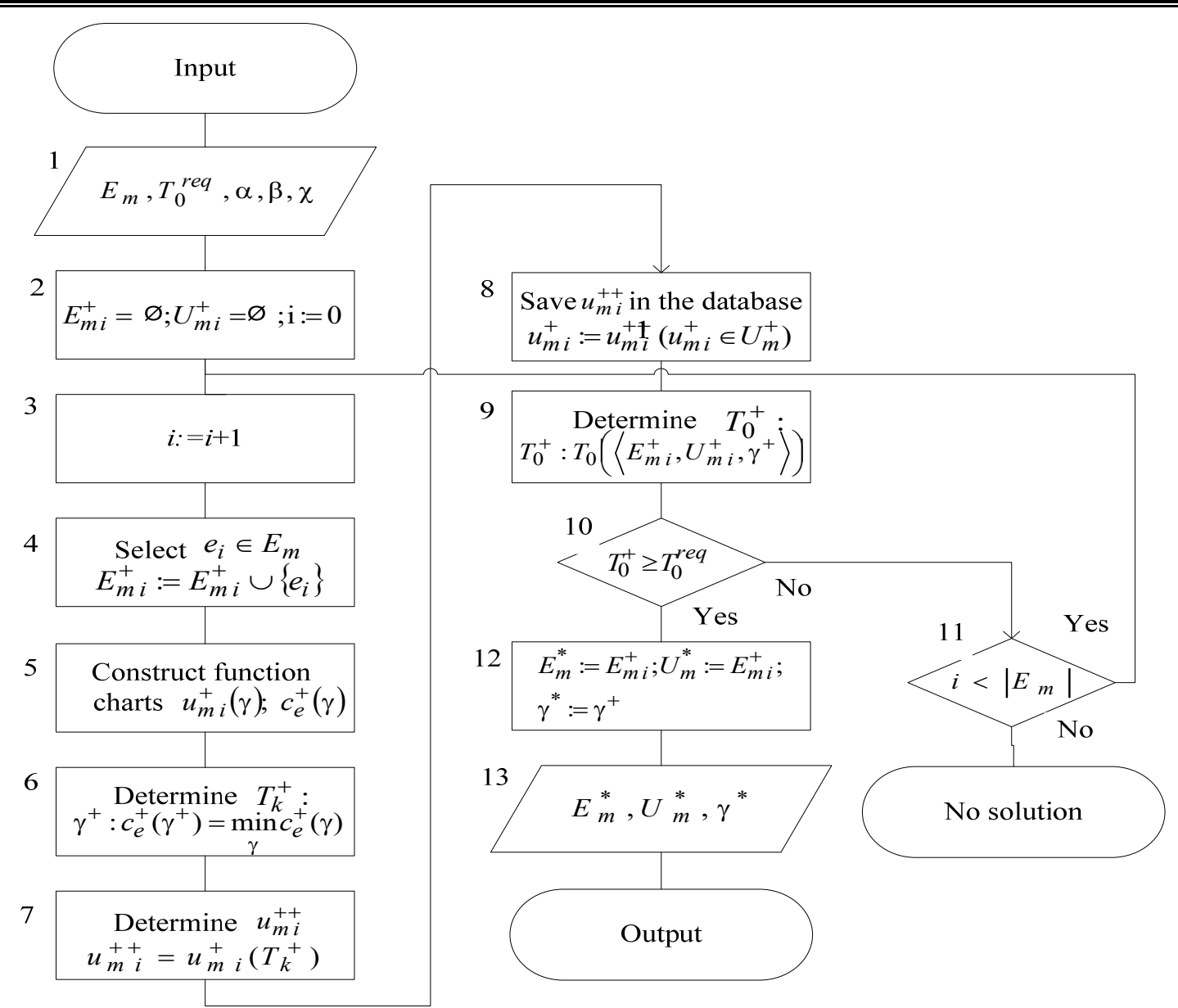

Figure 1 - Algorithmic model for optimal parameters search of the OCM strategy with adaptive change of the control period

For a three-parameter smoothing model $[14,15]$ :

$$
\begin{gathered}
\tilde{a}_{i}\left(t_{k+1}\right)=\left[L\left(t_{k}\right)+T\left(t_{k}\right)\right] \times S\left(t_{k+1-s}\right), \\
L\left(t_{k}\right)=\alpha \cdot \frac{a_{i}\left(t_{k}\right)}{S\left(t_{t-s}\right)}+(1-\alpha)\left[S\left(t_{k-1}\right)-T\left(t_{k-1}\right)\right], \\
T\left(t_{k}\right)=\beta\left(S\left(t_{k}\right)-S\left(t_{k-1}\right)\right)+(1-\beta) \cdot T\left(t_{k-1}\right), \\
S\left(t_{k}\right)=\chi \cdot \frac{a_{i}\left(t_{k}\right)}{L\left(t_{k}\right)}+(1-\gamma) \cdot S\left(t_{k-s}\right) .
\end{gathered}
$$

The function $u_{m i}^{+}(\gamma)$ determines the dependence of the optimal maintenance level of the $i$-th element on the ratio $\gamma$.

The value $u_{m i}^{+}(\gamma)$ is determined on the basis of the expression:

$$
u_{m i}^{+}(\gamma): c_{e}\left(E_{m i}^{+}, \mathbf{U}_{m i}^{+}, \gamma\right) \rightarrow \min _{u_{m i}}
$$

Function $c_{e}^{+}(\gamma)$ is the specific cost of operation obtained with the optimum value of the maintenance level $\mathbf{U}_{m i}^{+}(\gamma)$ :

(c) Lienkov S. V., Zhirov H. B., Tolok I. V., Lienkov Ye. S., 2020 DOI 10.15588/1607-3274-2020-1-7

$$
c_{e}^{+}(\gamma)=c_{e}\left(E_{m i}^{+}, \mathbf{U}_{m i}^{+}, \gamma\right)
$$

Statement 6 determines the optimal value of the ratio $\gamma^{+}$in the current step, which satisfies the condition:

$$
c_{e}^{+}\left(\gamma^{+}\right)=\min _{\gamma} c_{e}^{+}(\gamma) .
$$

Statement 7 determines the optimum value of the maintenance level:

$$
u_{m i}^{++}=u_{m i}^{+}\left(\gamma^{+}\right)
$$

Statement 8 saves the value $u_{m i}^{++}$in the DB as the optimal value for this step.

Statement 9 defines the value of the mean time between failures, obtained in the current search step $T_{0}^{+}=T_{0}\left(\mathrm{P}_{a m(i)}^{+}\right)$, and $\mathrm{P}_{a m(i)}^{+}=\left\langle E_{m i}^{+}, \mathbf{U}_{m i}^{+}, \gamma^{+}\right\rangle$.

Statement 10 verifies the compliance with the condition $T_{0}^{+} \geq T_{0}^{r e q}$. If the condition is satisfied, Statement 12 forms the final solution:

$$
\mathrm{P}_{a m c}^{*}:=\mathrm{P}_{a m(i)}^{+} .
$$


Thus, the solution search process finishes.

If Statement 9 does not comply with the condition $T_{0}^{+} \geq T_{0}^{r e q}$, Statement 10 verifies if all the elements from $E_{m}$ have already been used. If not, and $\left(i<\left|E_{m}\right|\right)$, it passes control to Statement 3 to continue the solution search process.

Statement 13 forms the optimal values of the adaptive maintenance parameters.

The algorithmic model of the task solution (2) completely coincides with the model developed above, except for the content of Statements 4 and 5 . The only difference lies in the fact that instead of the criterion $\min c_{\mathrm{e}}$ a criterion $\max K_{s s a}$ is used. Therefore, in Statement 4 a function chart $K_{s s a}^{+}(\gamma)$ is constructed, with the optimal value determined in Statement 5 on the basis of the condition:

$$
K_{s s a}^{+}\left(\gamma^{+}\right)=\max _{\gamma} K_{s s a}^{+}(\gamma)
$$

The content of all other operators remains unchanged.

Taking into account the aforementioned, one can formulate the following method of optimizing the parameters of the adaptive maintenance process of a complex radioelectronic facility:

1. Create a database of the REF, with the task of optimizing the adaptive maintenance parameters solved.

2. Specify the simulation parameters for ISMPN.

3. Determine the set of potentially maintained elements $E_{m}$ and the required mean time between failures based on the maintenance $T_{0}^{r e q}$.

4. Choose an item from the set of potentially maintained ones, with the highest failure rate, and perform modeling according to one of the criteria: $\min c_{e}$ or $\max K_{r e q}$. Determine the conditionally optimal maintenance parameters for one maintained element.

5. Determine the mean time between failures and compare with the required one. If the mean time between failures is less than required, add the second one, etc. to the list of maintained items, till the mean time between failures is no less than necessary.

6 . Determine the optimal parameters of adaptive maintenance.

\section{EXPERIMENTS}

The problem is solved using the ISMPN program. In each step of the task solving, actions are performed in accordance with the following procedure:

1) the formation of the current subset $E_{m i}^{+}$of the maintained elements (in the $i$-th step one element $E_{m}$ is added to the subset $E_{m i}^{+}$);

(C) Lienkov S. V., Zhirov H. B., Tolok I. V., Lienkov Ye. S., 2020 DOI 10.15588/1607-3274-2020-1-7
2) the search for a conditionally optimal solution $\mathrm{P}_{a m(i)}^{+}=\left\langle E_{m i}^{+}, \mathbf{U}_{m i}^{+}, \gamma^{+}\right\rangle \quad$ (by criterion $\min c_{e}$ or $\max K_{s s a}$ ) and determination of the mean time between failures $T_{0}^{+}$;

3) verification of compliance with the condition $T_{0}^{+} \geq T_{0}^{r e q}$. If the requirement is not satisfied, proceed to point 1 and continue solving the task. If the request is met, complete the closing point of the procedure;

4) acceptance of the conditionally optimal solution $\mathrm{P}_{a m(i)}^{+}$obtained in the final step as the final solution of the task $\mathrm{P}_{a m}^{*}:=\mathrm{P}_{a m(i)}^{+}$.

The procedure is illustrated by the example of the testing facility Test- 1 . The database for the facility was established. The facility contains 15 elements of different levels included in the set of denied elements $E_{0}$. For example, the set of potentially maintained elements $E_{m}$ comprises 5 least reliable elements from $E_{0}$. Table 1 shows the data on such elements. Mean time between failures is subject to the $D N$ distribution with the coefficient of variation of failure time of all elements $v_{i}=0.8$.

Cost and time characteristics of the facility Test-1: $\tau_{\text {repi }}=1 \mathrm{~h} ; \tau_{m i}=0.2$ hours; $C_{0 i}=10$ c.u.; $C_{\text {repi }}=$ 1 c.u.; $\quad C_{m i}=1$ c.u. $\quad\left(\forall i=\overline{1,\left|E_{m}\right|}\right) ; \quad \tau_{m c}=0.5 \mathrm{~h}$; $\tau_{\text {trou }}=1 \mathrm{~h} ; \tau_{m a}=1 \mathrm{~h}$.

Table 1 - Characteristics of potentially maintained elements of the facility Test-1

\begin{tabular}{|c|c|c|c|}
\hline $\begin{array}{c}\text { Element } \\
\text { number }\end{array}$ & Element name & $\begin{array}{c}\text { Mean failure time } \\
T_{c p i}, \mathrm{~h}\end{array}$ & $\begin{array}{c}\text { Cost of the } \\
\text { element } C_{0 i}, \\
\text { c.u. }\end{array}$ \\
\hline 1 & 132 & 10000 & 40 \\
2 & 12 & 14142 & 20 \\
3 & 11111 & 14142 & 20 \\
4 & $131-1$ & 20000 & 10 \\
5 & $131-2$ & 20000 & 10 \\
\hline
\end{tabular}

We specify the parameters of modeling and the environment for the ICM, namely: $T_{e}=20$ years; $N_{I}^{\max }=100 ; \varepsilon^{r e q}=0.2 ; \quad c_{s f}=10$ c.u./year; $c_{s m}=2$ c.u./year.

If maintenance for the facility Test- 1 is absent in such conditions, the following values are obtained: $T_{0}=1,210$ h; $\quad c_{e}=0.02997$ c.u. $/ \mathrm{h} ; \quad K_{s s a}=0.99835$. Permanent smoothing equals to $\beta=0.5$.

The required mean time between failures: $T_{0}^{r e q}=1.500 \mathrm{~h}$.

\section{RESULTS}

Optimization by criterion $\min c_{e}$.

The calculations are performed as follows: 
1. In step 1, we add element 132: $E_{m(1)}^{+}=\{132\}$ to the set $E_{m}^{+}$.

2. We launch the ISMPN program in the mode "Optimizing maintenance/adaptive maintenance" and specify the following variation parameters:

- for: $u_{m}: u_{m} \in[0.4 ; 0.8] ; \Delta u_{m}=0.05$;

- for: $\gamma: \gamma \in[0.2 ; 0.7] ; \Delta \gamma=0.05$.

Figure 2 shows the view of the PC screen after modeling is completed in step 1.

By the function chart $c_{e}^{+}(\gamma)$, we determine its minimum and corresponding conditionally optimal value $\gamma^{+}=0.45$. According to the chart $u_{m 1}^{+}(\gamma)$, we determine the optimal value of the maintenance level for element $132 u_{m 1}^{++}=u_{m 1}^{+}\left(\gamma^{+}\right)=0.40$.

As a result of the calculations performed in step 1, we obtain the following conventionally optimal solution: $\mathrm{P}_{a m(1)}^{+}=\left\langle E_{m 1}^{+}, \mathbf{U}_{m 1}^{+}, \gamma^{+}\right\rangle=\langle\{132\} ;\{0.40\} ; 0.45\rangle$.
3. According to the chart $T_{0}^{+}(\gamma)$, we determine the mean time between failures $T_{0}^{+}=1.386$ hours, which is achieved with these parameters (shown next to the chart on the right).

4. If the requirement $T_{0}^{+} \geq T_{0}^{\text {req }}$ is not fulfilled, we take the next step. But before proceeding to the next step, we enter the latest value of the maintenance level $u_{m 1}^{++}$ (for element 132) in the database.

The final modeling results are shown in Table 2.

To ensure the reliability level $T_{0}^{r e q}=1.500 \mathrm{~h}$, the parameters obtained in step 2: $\mathrm{P}_{a m c}^{*}=\mathrm{P}_{a m(2)}^{+}=\langle\{132,12\} ;\{0.40 ; 0.55\} ; 0.40\rangle$ are optimal parameters of the adaptive OCM by criterion $\min c_{e}$.

With the above parameters, the following values of indicators are provided:

$$
\begin{aligned}
& T_{0}\left(\mathrm{P}_{a m c}^{*}\right)=1.529 \mathrm{~h} ; c_{e}\left(\mathrm{P}_{a m c}^{*}\right)=0.02162 \mathrm{c.u} . / \mathrm{h} ; \\
& K_{s s a}\left(\mathrm{P}_{a m c}^{*}\right)=0.99825 .
\end{aligned}
$$

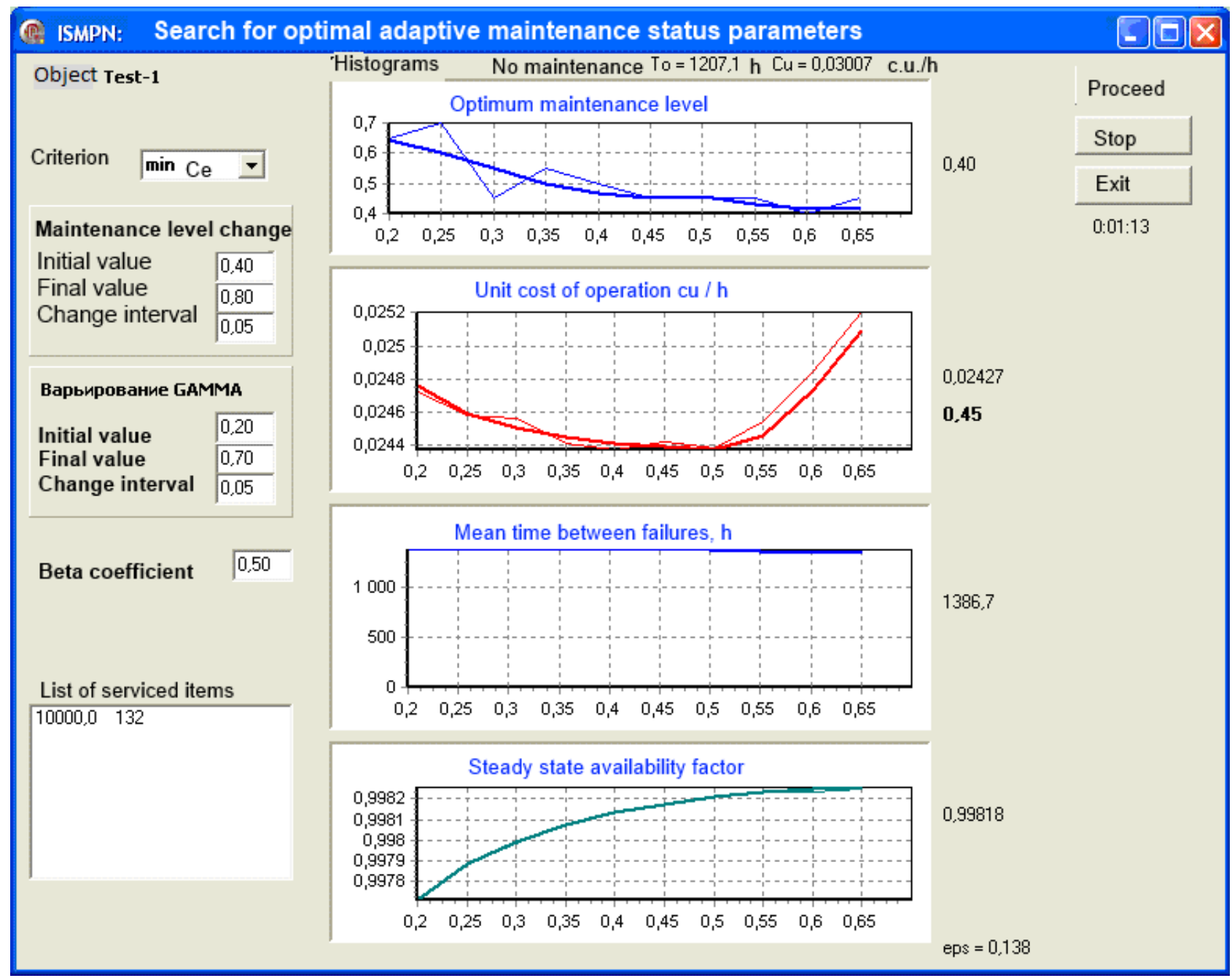

Figure 2 - View of the PC screen after modeling is completed in step 1 (criterion min $c_{e}$ ) 
The statistical error of the modeling results, with the above results obtained, is $\varepsilon=0.148$.

Optimization by criterion $\max K_{s s a}$.

1. In step 1 , we add element 132 to the set $E_{m}^{+}$: $E_{m(1)}^{+}=\{132\}$.

2. We launch the ISMPN program in the mode "Optimizing maintenance/adaptive maintenance" and specify the following variation parameters:

- for $u_{m}: u_{m} \in[0.4 ; 0.8] ; \Delta u_{m}=0.05$;

- for $\gamma: \gamma \in[0.4 ; 1.0] ; \Delta \gamma=0.05$.

The result of modeling shows that the function $K_{s s a}^{+}(\gamma)$ does not have a stable maximum, so we immediately proceed to step 2 and add element 12 to the set
$E_{m(1)}^{+}: E_{m(2)}^{+}=\{132,12\}$. Figure 3 shows the view of the PC screen after completing the simulation in Step 2.

In step 2, the maximum of the function $K_{s s a}^{+}(\gamma)$ is obtained at the value of the argument $\gamma^{+}=0.65$. According to the chart, we find conditionally optimal value of the maintenance level $u_{m 1}^{++}=u_{m 1}^{+}\left(\gamma^{+}\right)=0.65$. All these data are calculated in a programmatic manner and displayed to the right of the corresponding chart.

Thus, after completing step 2, we obtained a conventionally optimal solution:

$$
\mathrm{P}_{a m(2)}^{+}=\left\langle E_{m 2}^{+}, \mathbf{U}_{m 2}^{+}, \gamma^{+}\right\rangle=\langle\{132\} ;\{0.45\} ; 0.65\rangle .
$$

Table 2 - Results of calculation of conditionally optimal parameters of the adaptive maintenance strategy for the facility Test-1 (criterion $\min \mathrm{c}_{\mathrm{e}}$ )

\begin{tabular}{|c|c|c|c|c|c|c|c|}
\hline \multirow{2}{*}{$\begin{array}{l}\text { step } \\
\text { num- } \\
\text { ber } i\end{array}$} & \multicolumn{3}{|c|}{ Conditionally optimal parameters $\mathrm{P}_{a m(i)}^{+}$} & \multicolumn{4}{|c|}{$\begin{array}{l}\text { Values of indicators obtained under conditionally optimal pa- } \\
\qquad \text { rameters } \mathrm{P}_{a m(i)}^{+}\end{array}$} \\
\hline & $E_{m i}^{+}$ & $u_{m i}^{++}$ & $\gamma^{+}$ & $T_{0}^{+}, \mathrm{h}$ & $c_{e}^{+}$, c.u./h & $K_{s s a}^{+}$ & $\varepsilon$ \\
\hline 0 & - & - & - & 1207 & 0.03007 & 0.99834 & 0.135 \\
\hline 1 & $\{132\}$ & 0.40 & 0.45 & 1386 & 0.02427 & 0.99818 & 0.138 \\
\hline 2 & $\{132,12\}$ & 0.55 & 0.40 & 1529 & 0.02162 & 0.99825 & 0.148 \\
\hline 3 & $\{132,12,11111\}$ & 0.45 & 0.45 & 1706 & 0.01894 & 0.99840 & 0.153 \\
\hline 4 & $\{132,12,11111,131-1\}$ & 0.55 & 0.45 & 1868 & 0.01743 & 0.99849 & 0.143 \\
\hline 5 & $\{132,12,11111,131-1,131-2\}$ & 0.56 & 0.40 & 2057 & 0.01603 & 0.99852 & 0.173 \\
\hline
\end{tabular}

(C. ISMPN: Search for optimal adaptive maintenance status parameters

Object Test-1

Adaptive maintenance

Criterion

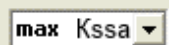

Maintenance level change

Initial value

Final value

$\frac{\square, 40}{0,80}$

Change interval 0,05

Варьирование GAMMA

Initial value

Final value

Change interval 0,05

Beta coefficient $\lcm{0,50}$

List of serviced items

10000,0132

$14142,1 \quad 12$

\section{Histograms No maintenance $T_{0}=1219,7 \mathrm{~h} \quad \mathrm{Cu}=0,02970$ c.u. $/ \mathrm{h}$}

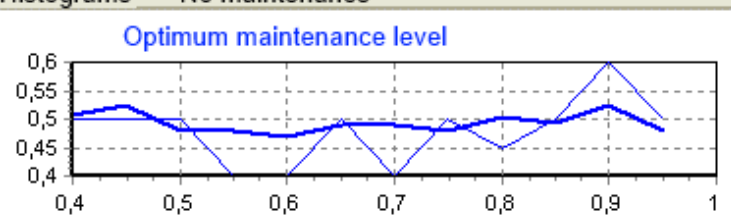

0.45

0 回

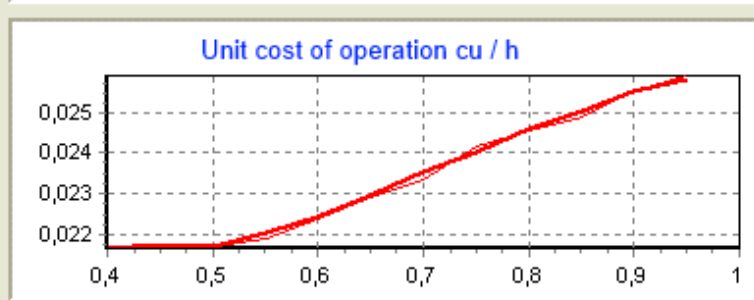

0,02289

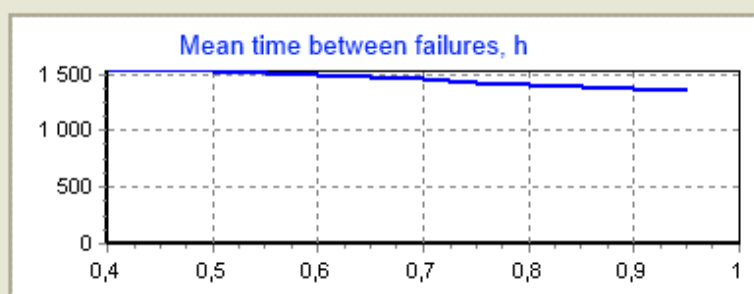

1469,3

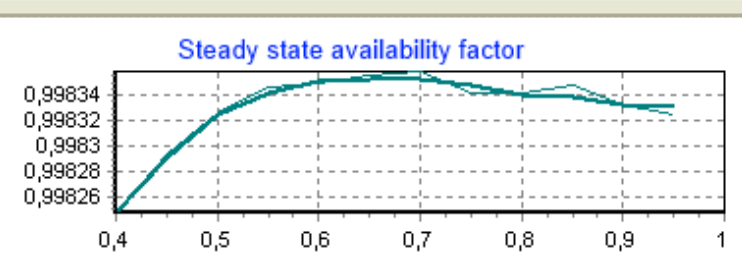

0,99836

0,65

eps $=0,146$

\begin{tabular}{|l|}
\hline Proceed \\
\hline Stop \\
\hline Exit \\
\hline $0: 00: 43$ \\
\hline
\end{tabular}

0:00:43 
3. According to the chart $T_{0}^{+}(\gamma)$, we determine the mean time between failures $T_{0}^{+}=1469 \mathrm{~h}$, which is achieved with these parameters (displayed along with the graph on the right).

4. If the requirement $T_{0}^{+} \geq T_{0}^{\text {req }}$ is not satisfied, we proceed to the next step. However, as before, we enter the latest value of the maintenance level $u_{m 1}^{++}=0.45$ in the database.

Table 3 shows the complete data obtained for all 5 steps (for all elements of the set $E_{m}$ ).

For the requirement $T_{0}^{r e q}=1.500 \mathrm{~h}$, the parameters, obtained in step 3, are optimal for the parameters of the adaptive maintenance strategy by the criterion $\max K_{s s a}$ :

$$
\mathrm{P}_{a m \kappa}^{*}=\mathrm{P}_{a m(3)}^{+}=\langle\{132,12,11111\} ;\{0.4 ; 0.45 ; 0.5\} ; 0.65\rangle \text {. }
$$

With the above parameters, the following values are provided:

$$
\begin{aligned}
& T_{0}\left(\mathrm{P}_{a m \kappa}^{*}\right)=1.616 \mathrm{~h} ; c_{\mathrm{e}}\left(\mathrm{P}_{a m \kappa}^{*}\right)=0.02048 \text { u.c. } / \mathrm{h} ; \\
& K_{\text {ssa }}\left(\mathrm{P}_{a m \kappa}^{*}\right)=0.99846 .
\end{aligned}
$$

The statistical error of the modeling results, with the above results obtained, is $\varepsilon=0.152$.

\section{DISCUSSION}

The analysis of the task solution results with regard to optimization of adaptive maintenance parameters by two different criteria show that the solutions $-\mathrm{P}_{a m \kappa}^{*}$ and $\mathrm{P}_{a m c}^{*}$, by all indicators $\mathrm{P}_{a m \kappa}^{*}$, are better than the solution $\mathrm{P}_{a m c}^{*}$. Table 4 shows the compared parameters.

The table also shows that the advantage of the solution $\mathrm{P}_{a m \kappa}^{*}$ is obtained only at the expense of a greater number of maintained elements: according to the solution $\mathrm{P}_{a m \kappa}^{*}$, the number of the maintained elements is equal to 3 , and according to the solution $\mathrm{P}_{a m c}^{*}$, it equals to 2 . This result is expectable, since in the output data cost and time spent on maintenance are very insignificant and equal for all elements.

\begin{tabular}{|c|c|c|c|c|c|}
\hline \multirow[b]{2}{*}{$\begin{array}{l}\text { Main- } \\
\text { tenance } \\
\text { para- } \\
\text { meters }\end{array}$} & \multirow[b]{2}{*}{$\begin{array}{l}\text { Optimi- } \\
\text { zation } \\
\text { crite- } \\
\text { rion }\end{array}$} & \multirow{2}{*}{$\begin{array}{l}\text { Number } \\
\text { of the } \\
\text { main- } \\
\text { tained } \\
\text { elements } \\
\left|E_{m}\right|\end{array}$} & \multicolumn{3}{|c|}{ Compared parameters } \\
\hline & & & $\begin{array}{c}T_{0}, \\
\mathrm{~h}\end{array}$ & $\begin{array}{c}c_{e}, \\
\text { c.u./h }\end{array}$ & $K_{s s a}$ \\
\hline $\begin{array}{l}\mathrm{P}_{a m c}^{*} \\
\mathrm{P}_{a m \kappa}^{*}\end{array}$ & $\begin{array}{l}\min c_{e} \\
\max K_{s s a}\end{array}$ & $\begin{array}{l}2 \\
3\end{array}$ & $\begin{array}{l}1529 \\
1616\end{array}$ & $\begin{array}{l}0.02162 \\
0.02048\end{array}$ & $\begin{array}{l}0.99825 \\
0.99846\end{array}$ \\
\hline $\mathrm{P}_{a m c(3)}^{+}$ & $\min c_{e}$ & 3 & 1706 & 0.01894 & 0.99840 \\
\hline
\end{tabular}

Table 4 - Comparative data of the optimal parameters of the adaptive maintenance of facility Test-1

The results obtained in this example also show that in the case of three maintained elements, the conditionally optimal solution $\mathrm{P}_{a m(3)}^{+}$, obtained by the criterion $\min c_{e}$, is much better than both solutions $\mathrm{P}_{a m c}^{*}$ and $\mathrm{P}_{a m \kappa}^{*}$.

The obtained results adequately demonstrate the peculiarities of the simulation model of optimizing the parameters of the adaptive maintenance strategy, as well as the possibility of application of the modeling results obtained.

\section{CONCLUSIONS}

The simulation model of the process of adaptive maintenance of a complex radio-electronic facility is developed in the work. The essence of the simulation model is that by gradually adding the least reliable elements to a set of elements to be maintained, and simulating random moments of the failure time of the facility elements, the model calculates the optimal parameters of maintenance with the adaptive time of the technical condition control.

The scientific novelty of the research is to improve the simulation model of the process of adaptive maintenance of a complex radio-electronic facility, which, unlike available ones, is based on the algorithmic model and algorithmic optimization techniques used in the software package of the ISMPN. As a method of optimization, we use the method of directed search within the

\begin{tabular}{|c|c|c|c|c|c|c|c|}
\hline \multirow{2}{*}{$\begin{array}{l}\text { Step } \\
\text { num- } \\
\text { ber } i\end{array}$} & \multicolumn{3}{|c|}{ Conditionally optimal parameters $\mathrm{P}_{a m(i)}^{+}$} & \multicolumn{4}{|c|}{$\begin{array}{l}\text { Values of indicators obtained under conditionally optimal pa- } \\
\text { rameters } \mathrm{P}_{a m(i)}^{+}\end{array}$} \\
\hline & $E_{m i}^{+}$ & $u_{m i}^{++}$ & $\gamma^{+}$ & $T_{0}^{+}, \mathrm{h}$ & $c_{e}^{+}$, c.u. $/ \mathrm{h}$ & $K_{s s a}^{+}$ & $\varepsilon$ \\
\hline 0 & - & - & - & 1219 & 0,02970 & 0,99834 & 0,137 \\
\hline 1 & $\{132\}$ & - & - & - & - & - & - \\
\hline 2 & $\{132,12\}$ & 0,45 & 0,65 & 1469 & 0,02289 & 0,99836 & 0,146 \\
\hline 3 & $\{132,12,11111\}$ & 0,50 & 0,65 & 1616 & 0,02048 & 0,99846 & 0,152 \\
\hline 4 & $\{132,12,11111,131-1\}$ & 0,55 & 0,55 & 1815 & 0,01801 & 0,99853 & 0,164 \\
\hline 5 & $\{132,12,11111,131-1,131-2\}$ & 0,40 & 0,60 & 1941 & 0,01721 & 0,99860 & 0,167 \\
\hline
\end{tabular}

Table 3 - Results of calculations of conditionally optimal parameters of an adaptive maintenance strategyfor the facility Test-1 (criterion $\max \mathrm{K}_{\mathrm{ssa}}$ ) 
scope of the maintenance parameters; as a mathematical model of reliability, we use the DN distribution for electronic components, and DM distribution for mechanical components, with the scheduled time interval to the next maintenance determined on the basis of the threeparameter exponential smoothing model, which enables to significantly simplify and automate the process of studying the reliability of indicators and optimization of adaptive maintenance parameters of a complex radioelectronic facility.

The practical value of the results obtained lies in developing software which optimizes the maintenance parameters and predicts reliability indicators and operation cost for the given REF. The results obtained are to be used when determining the requirements for the parameters of operation of both new facilities and those of the available stock.

Prospects for further research lie in creating simulation models and software tools for optimizing the parameters of the process of scheduled maintenance of REFs, maintenance and repair procedures of the REF groups.

\section{ACKNOWLEDGEMENTS}

The work was performed as part of the state budget research topic of the Military Institute of the Taras Shevchenko Kiev National University, on the theme "Development of models and methods for determining the optimal parameters", code "Optimization" (state registration number 0118U004378).

\section{REFERENCES}

1. Lenkov S., Tolok I., Tsitsarev V., Zhyrov G., Lenkov E., Khlaponin Yu., Borowik B. eds. Forecasting reliability of complex technology objects. Parameters optimization of their technical exploitation: monograph. Bielsko-Biala, Publishing house «BEL», 2018, 253 p.

2. Zhirov G. B., Lenkov E. S. Algoritmi modeliuvannia protsesiv tehnichno-go obslugovuvannia za stanom skladnih radioelektronnih ob'€ktiv, Radio Electronics, Computer Science, Control, 2018, No. 2(45), pp. 14-21. DOI: 10.15588/1607-3274-2018-2-2.

3. Zhirov G.B., Lenkov C. S., Tolok I. V. Analiz matematichnih modelei tehnichnogo obslugovuvannia skladnih tehnichnih ob ektiv, Zbirnik naukovih prats' Harkivs'kogo universitetu Povitrianih Sil, 2017, Vip.2(51), pp. 153-158.

4. Lenkov S. V., Seliukov O. V., Tolok I. V. i dr. Matematichna model' protsesiv vitrachannia ta popovnen-nia resursu ugrupovannia skladnih tehnichnih ob'ektiv, Nauka tehnika Povitrianih Sil ZSU, 2018, No. 2 (31), pp. 174-181.

5. Faddoul R., Raphael W., Chateauneuf A.Maintenance optimization of series systems subject to reliability constraints,
Reliability Engineering \& System Safety, 2018, No. 180, pp. 179-188. DOI: 10.1016/j.ress.2018.07.016.

6. Khatab A., Diallo C., Venkatadri U., Liu Z., Aghezzaf E.-H. Optimization of the joint selective maintenance and repairperson assignment problem under imperfect maintenance, Computers \& Industrial Engineering, 2018, No. 125, pp. 413-422. DOI: 10.1016/j.cie.2018.09.012.

7. Martinod R., Bistorin O., Leonel F., Castañeda L., Rezg N. Maintenance policy optimisation for multi-component systems considering degradation of components and imperfect maintenanceactions, Computers \& Industrial Engineering, 2018, pp. 100-112. DOI: 10.1016/j.cie.2018.07.019.

8. Shayesteh E., Yu J., Hilber P. Maintenance optimization of power systems with renewable energy sources integrated, Energy, 2018, No. 149, pp. 577-586. DOI: 10.1016/j.energy.2018.02.066.

9. Briš R., Byczanski P., Goňo R., Rusek S. Discrete maintenance optimization of complex multi-component systems, Reliability Engineering \& System Safety, 2017, No. 168, pp. 80-89. DOI: 10.1016/j.ress.2017.04.008.

10. Belyi D., Popova E., Morton D., Damien P. Bayesian failure-rate modeling and preventive maintenance optimization, European Journal of Operational Research, 2017, No. 262, Issue 3, pp. 1085-1093. DOI: 10.1016/j.ejor.2017.04.019.

11. Rawat M., Kumar L. B. Novel approach for machine tool maintenance modelling and optimization using fleet system architecture, Computers \& Industrial Engineering, 2018, No. 126, pp. 47-62. DOI: 10.1016/j.cie.2018.09.006.

12. Wijk O., Andersson P., Block J., Righard T. Phase-out maintenance optimization for an aircraft fleet, International Journal of Production Economics, 2017, No. 188, pp. 105115. DOI: 10.1016/j.ijpe.2017.01.002.

13. Ye Yixin, Grossmann I. E., Pinto J. M., Ramaswamy S. Modeling for reliability optimization of system design and maintenance based on Markov chain theory, Computers \& Chemical Engineering, 2019, No. 124, pp. 381-404. DOI: 10.1016/j.compchemeng.2019.02.016.

14. Vartanjan V. M., Romanenkov Ju. O., Revenko D. S., i dr. Modeljuvannja dynamichnyh procesiv po chasovyh rjadah: monografija. Harkiv, Nac. aerokosm. un-t im. M. Je. Zhukovs'kogo «Har'k. aviac. in-t», 2012, 266 p.

15. Rendon-Sanchez J., Menezes L. Structural combination of seasonal exponential smoothing forecasts applied to load forecasting, European Journal of Operational Research, 2019, Vol. 275, Issue 1, pp. 916-924. DOI: 10.1016/j.ejor.2018.12.013.

16. Ashurkov I. S., Leshko N. A., Kakaev V. V. Ispol'zovanie metoda priamogo perebora dlia optimizatsii prostranstvennoi struktury mnogopo-zitsionnoi radiolokatsionnoi sistemy [Elektr. resurs]. Rezhim dostupa http://trudymai.ru/published.php?ID=69752

Received 27.05.2019 Accepted 24.12.2019.

\section{УДК.004.052}

\section{ІМІТАЦЙНА МОДЕЛЬ ПРОЦЕСУ АДАПТИВНОГО ТЕХНІЧНОГО ОБСЛУГОВУВАННЯ СКЛАЛНОГО} РАДІОЕЛЕКТРОННОГО ОБ'ЄКТА

Лснков С. В. - д-р техн. наук, проф. головний науковий співробітник науково-дослідного центру Військового інституту Київського національного університету імені Тараса Шевченка, Київ, Україна.

Жиров Г. Б. - канд. техн. наук, с.н.с., доцент кафедри радіотехніки та радіоелектронних систем Київського національного університету імені Тараса Шевченка, Київ, Україна.

Толок І. В. - канд. пед. наук, начальник Військового інституту Київського національного університету імені Тараса Шевченка, Київ, Україна; 
Лснков Є. С. - канд. техн. наук, старший науковий співробітник центрального науково-дослідного інституту Збройних Сил України, Київ, Україна.

\section{АНОТАЦІЯ}

Актуальність. Процес технічного обслуговування (ТО) сучасних об'єктів РЕТ направлений на підтримання справності чи працездатності об’єктів під час їх технічної експлуатації. Вимоги, щодо досягнення високої надійності експлуатації часто знаходяться в суперечності з іншими необхідними характеристиками, такими як зменшення розмірів виробу, отримання високої точності, зниження вартості експлуатації і т. д. Тому питання, оптимального вибору параметрів ТО для вирішення різних задач експлуатації та із застосуванням різних критеріїв, $є$ актуальною.

Мета. Метою даної роботи є розробка підходів щодо визначення оптимальних параметрів процесу адаптивного технічного обслуговування.

Метод. В рамках загальної імітаційної статистичної моделі процесу технічного обслуговування і ремонту складного об'єкту РЕТ розроблена імітаційна модель оптимізації параметрів однієї із стратегій ТО. Загальна імітаційна статистична модель призначена для моделювання процесу проведення ТО и ремонту об'єкта РЕТ з метою прогнозування показників надійності та вартості експлуатації об'єкта. Оптимізація параметрів ТО покращує, як показники надійності самого об'єкта так і економічні показники експлуатації об'єкта у цілому. Оптимізація параметрів здійснюється за критерієм мінімуму питомої вартості експлуатації об'єкта РЕТ або за критерієм максимуму коефіцієнта технічного використання. Обмеженням в обох випадках виступає необхідне значення середнього наробітку на відмову об'єкта, а в якості методу оптимізації використовується метод спрямованого перебору у просторі параметрів ТО. У процесі пошуку оптимального рішення може приймати участь людина-експерт, яка залучається для аналізу проміжних даних і для прийняття рішення про закінчення процесу пошуку.

Результати. Удосконалена методика оптимізації параметрів ТО являє собою математичне та алгоритмічне підгрунтя для загального програмного забезпечення імітаційної статистичної моделі процесу технічного обслуговування і ремонту. Розроблений метод програмно реалізований і досліджений при вирішенні тестових завдань. Результати обчислювального експерименту проілюстровані у табличній формі.

Висновки. У роботі розроблена імітаційна модель процесу адаптивного технічного обслуговування складного радіоелектронного об'єкта. Модель дозволяє суттєво спростити та автоматизувати процес дослідження та оптимізації параметрів адаптивного технічного обслуговування складного радіоелектронного об'єкта. Шляхом покрокового додавання найменш надійних елементів до множини елементів, які підлягають обслуговуванню, та моделюванню випадкових моментів часу відмов елементів об'єкта, імітаційна модель розраховує оптимальні параметри технічного обслуговування 3 адаптивним часом проведення контролю технічного стану. Імітаційна модель базується на розроблених в роботі алгоритмічній моделі та методиці оптимізації параметрів процесу адаптивного технічного обслуговування та працює у середовищі програмного засобу ISMPN. В якості методу оптимізації використовується метод спрямованого перебору у просторі параметрів TO, а за математичну модель безвідмовності взятий $D N$ розподіл, для електронних компонентів та $D M$ розподіл, для механічніх компонентів.

Практичне значення роботи полягає у розробці програмного забезпечення, яке оптимізує параметри ТО та прогнозує показники надійності та вартості експлуатації для заданого об'єкта РЕТ. Отримані результати пропонується використовувати при визначені вимог до параметрів експлуатації як нових об'єктів, так і об'єктів старого парку.

КЛЮЧОВІ СЛОВА: оптимізація параметрів технічного обслуговування, адаптивне технічне обслуговування.

\section{УДК.004.052}

\section{ИМИТАЦИОННАЯ МОДЕЛЬ ПРОЦЕССА АДАПТИВНОГО ТЕХНИЧЕСКОГО ОБСЛУЖИВАНИЯ}

\section{СЛОЖНОГО РАДИОЭЛЕКТРОННОГО ОБЪЕКТА}

Ленков С. В. - д-р. техн. наук, проф. главный научный сотрудник научно-исследовательского центра Военного института Киевского национального университета имени Тараса Шевченко, Киев, Украина.

Жиров Г. Б. - канд. техн. наук, с.н.с., доцент кафедры радиотехника и радиоэлектронных систем Киевского национального университета имени Тараса Шевченко, Киев, Украина.

Толок I. В. - канд. пед. наук, начальник Военного института Киевского национального университета шимени Тараса Шевченко, Киев, Украина.

Лєнков С.С. - канд. техн. наук, старший научный сотрудник центрального научно-исследовательского института Вооруженных Сил Украины, Киев, Украина.

\section{АННОТАЦИЯ}

Актуальность. Процесс технического обслуживания (ТО) современных объектов РЕТ направлен на поддержание исправности или работоспособности объектов при их технической эксплуатации. Требования, по достижению высокой надежности эксплуатации часто находятся в противоречии с другими необходимыми характеристиками, такими как уменьшение размеров изделия, получения высокой точности, снижение стоимости эксплуатации и т.д. Поэтому вопрос, оптимального выбора параметров ТО для решения различных задач эксплуатации с применением различных критериев, является актуальной.

Цель. Целью данной работы является разработка подходов к определению оптимальных параметров процесса адаптивного технического обслуживания.

Метод. В рамках общей имитационной статистической модели процесса технического обслуживания и ремонта сложного объекта РЕТ разработана имитационная модель оптимизации параметров одной из стратегий ТО. Общая имитационная статистическая модель предназначена для моделирования процесса проведения ТО и ремонта объекта РЕТ с целью прогнозирования показателей надежности и стоимости эксплуатации объекта. Оптимизация параметров ТО улучшает, как показа- 
тели надежности самого объекта, так и экономические показатели эксплуатации объекта в целом. Оптимизация параметров осуществляется по критерию минимума удельной стоимости эксплуатации объекта РЕТ или по критерию максимума коэффициента технического использования. Ограничением в обоих случаях выступает требуемое значение средней наработки на отказ объекта, а в качестве метода оптимизации используется метод направленного перебора в пространстве параметров ТО. В процессе поиска оптимального решения может принимать участие человек-эксперт, который привлекается для анализа промежуточных данных и для принятия решения об окончании процесса поиска.

Результаты. Усовершенствованная методика оптимизации параметров ТО представляет собой математическую и алгоритмическую основу для общего программного обеспечения имитационной статистической модели процесса технического обслуживания и ремонта. Разработанный метод программно реализован и исследован при решении тестовых заданий. Результаты вычислительного эксперимента проиллюстрированы в табличной форме.

Выводы. В работе разработана имитационная модель процесса адаптивного технического обслуживания сложного радиоэлектронного объекта. Модель позволяет существенно упростить и автоматизировать процесс исследования и оптимизации параметров адаптивного технического обслуживания сложного радиоэлектронного объекта. Путем пошагового добавления наименее надежных элементов к множеству элементов подлежащих обслуживанию и моделированию случайных моментов времени отказов элементов объекта, имитационная модель рассчитывает оптимальные параметры технического обслуживания с адаптивным времени проведения контроля технического состояния. Имитационная модель базируется на разработанных в работе алгоритмической модели и методике оптимизации параметров процесса адаптивного технического обслуживания и работает в среде программного средства ISMPN. В качестве метода оптимизации используется метод направленного перебора в пространстве параметров TO, а за математическую модель безотказности взято DN распределение, для электронных компонентов и DM распределение, для механических компонентов.

Практическое значение работы состоит в разработке программного обеспечения, которое оптимизирует параметры ТО и прогнозирует показатели надежности и стоимости эксплуатации для заданного объекта РЕТ. Полученные результаты предлагается использовать при определении требований к параметрам эксплуатации, как новых объектов, так и объектов старого парка.

КЛЮЧЕВЫЕ СЛОВА: оптимизация параметров технического обслуживания, адаптивное техническое обслуживание.

\section{ЛІТЕРАТУРА / ЛИТЕРАТУРА}

1. Forecasting reliability of complex technology objects. Parameters optimization of their technical exploitation: monograph / [eds.: S. Lenkov, I. Tolok, V. Tsitsarev, G. Zhyrov, E. Lenkov, Yu. Khlaponin, B. Borowik]. - Bielsko-Biala: Publishing house «BEL », 2018. $-253 \mathrm{p}$.

2. Жиров Г.Б. Алгоритми моделювання процесів технічного обслуговування за станом складних радіоелектронних об'єктів / Г. Б. Жиров, Е. С. Ленков // Радіоелектроніка, інформатика, управління. - 2018. - №2(45). - С. 14-21. DOI 10.15588/1607-3274-2018-2-2.

3. Жиров Г. Б. Аналіз математичних моделей технічного обслуговування складних технічних об єктів / Г. Б. Жиров, €. С. Лєнков, І. В. Толок // Збірник наукових праць Харківського університету Повітряних Сил. - 2017. Вип. 2(51). - С. 153-158.

4. Математична модель процесів витрачання та поповнення ресурсу угруповання складних технічних об'єктів / [С. В. Лєнков, О. В.Сєлюков, І. В. Толок и др.] // Наука і техніка Повітряних Сил ЗСУ. - 2018. - №. 2 (31). - С. 174 181.

5. Faddoul R. Maintenance optimization of series systems subject to reliability constraints / R. Faddoul, W. Raphael, A.Chateauneuf // Reliability Engineering \& System Safety. 2018. - № 180. - P. 179-188. DOI: 10.1016/j.ress.2018.07.016.

6. Optimization of the joint selective maintenance and repairperson assignment problem under imperfect maintenance / [A. Khatab, C. Diallo, U. Venkatadri, Z. Liu, E.-H. Aghezzaf] // Computers \& Industrial Engineering. - 2018. - № 125. P. 413-422. DOI: 10.1016/j.cie.2018.09.012.

7. Maintenance policy optimisation for multi-component systems considering degradation of components and imperfect maintenanceactions / [R. Martinod, O. Bistorin, F. Leonel et al.] // Computers \& Industrial Engineering. - 2018. - P. 100-112. DOI:10.1016/j.cie.2018.07.019.

8. Shayesteh E. Maintenance optimization of power systems with renewable energy sources integrated / E. Shayesteh, J. Yu,
P. Hilber // Energy. - 2018. - №. 149. - P. 577-586. DOI: 10.1016/j.energy.2018.02.066.

9. Discrete maintenance optimization of complex multicomponent systems / [Briš R., Byczanski P., Goňo R., Rusek S.] // Reliability Engineering \& System Safety. - 2017. - №. 168. P. 80-89. DOI: 10.1016/j.ress.2017.04.008.

10. Bayesian failure-rate modeling and preventive maintenance optimization / [Dmitriy Belyi, Elmira Popova, David P.Morton, Paul Damien] // European Journal of Operational Research. 2017. - № 262, Issue 3. - P. 1085-1093. DOI: 10.1016/j.ejor.2017.04.019.

11. Rawat M. Novel approach for machine tool maintenance modelling and optimization using fleet system architecture / M. Rawat, B. K. Lad // Computers \& Industrial Engineering. 2018. - № 126. - P. 47-62. DOI: 10.1016/j.cie.2018.09.006.

12. Phase-out maintenance optimization for an aircraft fleet / [O. Wijk, P. Andersson, J. Block, T. Righard] //International Journal of Production Economics. - 2017. - № 188. - P. 105115. DOI: 10.1016/j.ijpe.2017.01.002.

13. Modeling for reliability optimization of system design and maintenance based on Markov chain theory / [Ye Yixin, I. E. Grossmann, J. M. Pinto, S. Ramaswamy] // Computers \& Chemical Engineering. - 2019. - № 124. - P. 381-404. DOI: 10.1016/j.compchemeng.2019.02.016.

14. Моделювання динамічних процесів по часових рядах: монографія: / [В. М. Вартанян, Ю. О. Романенков, Д. С. Ревенко, и др.] - Х. : Нац. аерокосм. ун-т ім. М. Є. Жуковського «Харьк. авіац. ін-т», 2012. - 266 с.

15. Rendon-Sanchez J. Structural combination of seasonal exponential smoothing forecasts applied to load forecasting / J. RendonSanchez, L. Menezes // European Journal of Operational Research. - 2019. - Vol. 275, Issue 1. - P. 916-924. DOI: 10.1016/j.ejor.2018.12.013.

16. Ашурков И. С. Использование метода прямого перебора для оптимизации пространственной структуры многопозиционной радиолокационной системы [Электр. ресурс] / И. С. Ашурков, Н. А. Лешко, В. В. Какаев. - Режим доступа http://trudymai.ru/published.php?ID=69752. 